\title{
Morphological and Polymerase Chain Reaction-Restriction Fragment Lenght Polymorphism Characterization of Biomphalaria kuhniana and Biomphalaria amazonica from Colombia
}

\author{
Luz E Velásquez*, Roberta L Caldeira, Victoria Estrada****, Omar S Carvalho/+
}

Centro de Pesquisas René Rachou-Fiocruz, Av. Augusto de Lima 1715, 30190-002 Belo Horizonte, MG, Brasil *Laboratorio de Malacología Medica, Universidad de Antioquia, Colombia **Grupo de Sistemática Molecular, Universidad Nacional de Colombia, Medellín, Colombia

In Colombia, five Biomphalaria planorbid species are known: B. kuhniana, B. straminea, B. peregrina, B. canonica and B. oligoza (var. B. philippiana). Among them, B. straminea is intermediate host of Schistosoma mansoni and B. peregrina has been found to be experimentally susceptible to this parasite. B. straminea is commonly confused with $\mathrm{B}$. kuhniana and they have been clustered together with $\mathrm{B}$. intermedia in the complex named $\mathrm{B}$. straminea. The difficulties involved in the specific identification, based on morphological data, have motivated the use of new techniques as auxiliary tools in cases of inconclusive morphological identification of such planorbid. In the present study, five Biomphalaria populations from the Colombian Amazon region and from Interandian Valleys were morphologically identified and characterized by polymerase chain reaction-restriction fragment lenght polymorphism directed at the internal transcribed spacer region of the rRNA gene, followed by digestion of the generated fragment with restriction enzymes (DdeI, AluI, RsaI, MvaI and HaeIII). Known profiles of the Brazilian species B. straminea, B. peregrina, B. kuhniana, B. intermedia and B. amazonica, besides B. kuhniana from Colombia, were used for comparison. The five populations under study were morphologically and molecularly identified as B. kuhniana and B. amazonica.

Key words: Biomphalaria kuhniana - Biomphalaria amazonica - snails - polymerase chain reaction - restriction fragment length polymorphism - Colombia

The Colombian snail fauna of the genus Biomphalaria is represented thus far by five species: $B$. kuhniana (DeJong et al. 2001), B. peregrina (Malek 1985), B. straminea (Barbosa 1968), B. canonica and B. oligoza var. B. philippiana (Uribe 1950). Among them, $B$. straminea is intermediate host of Schistosoma mansoni, being one of the main species responsible for schistosomiasis transmission in many localities of the Northeastern region of Brazil. This species was described by Dunker (1848) and according with Paraense (1963) "The type locality was vaguely mentioned as South America, where several species answering to that description are known to occur" and "Martens (1873) restricted the type locality of $P$. stramineus to Venezuela (Lagunilla and Caracas), and also referred it to the State of Ceará, Brazil". Being experimentally susceptible to $S$. mansoni, the species $B$. peregrina is regarded as a potential host of the trematode (Paraense \& Corrêa 1973). Concerning the epidemiological importance of $B$. straminea for schistosomiasis, this species is commonly confused with $B$. kuhniana and $B$. intermedia. For this reason, these three species were clustered into a group named $B$. straminea complex (Paraense

Work partially supported by Fapemig.

${ }^{+}$Corresponding author. Fax: + 55-31-3295.3115. E-mail: omar@cpqrr.fiocruz.br

Receibed 11 April 2002

Accepted 12 June 2002
1988). The difficulties involved in specific identification based on morphological characters have motivated the use of more modern techniques such as molecular biology.

The type locality of B. kuhniana (Clessin, 1883) is Paramaribo, Surinam but it is also found in Cayenne, French Guyana (Floch \& Fauran 1954a,b, Floch \& Lajudie 1945), Venezuela (Baker 1930), Tucuruí, Pará, Brazil (Paraense 1988), and Panama (Paraense - pers. commun. 1998). Regarding susceptibility, Floch and Fauran (1954b) showed that $B$. kuhniana is resistant to $S$. mansoni infection.

The type locality of B. amazonica Paraense, 1966, is Manaus, Amazonas, Brazil. To date, its distribution is restricted to the Brazilian states of Acre, Amazonas, Rondônia (Paraense 1983), Mato Grosso (Paraense 1983), Mato Grosso do Sul (Dorval \& Silva 1990) and Bolivia (Pontier et al. 2002). Experiments on susceptibility showed that such species is a potential host of S. mansoni (Corrêa \& Paraense 1971, Paraense \& Corrêa 1985). Vidigal et al. (2000a) characterized this snail by polymerase chain reaction-restriction fragment lenght polymorphism (PCRRFLP) with the enzyme DdeI and detected three speciesspecific profiles in specimens from the same or different localities.

The PCR-RFLP technique has been successfully used in studies on Biomphalaria (Vidigal et al. 1998, 2000a, Caldeira et al. 1998, 2000, Spatz et al. 1999), Oncomelania (Hope \& McManus 1994) and Bulinus species (Stothard et al. 1996, Stothard \& Rollinson 1997). This methodology was also used for molecular identification of Mammalia, 
Coleoptera and Platyhelminthes (Clark et al. 2001, Dynes et al. 2001, Verkaar et al. 2002) and for the distinction of cryptic species within the Trypanosoma brucei group (Agbo et al. 2001). The technique is based on the amplification of a particular genomic DNA region, followed by digestion of the generated fragment with restriction enzymes. Considering the simplicity and easy execution of the technique, in the current study we used PCR-RFLP and morphological identification in order to characterize Biomphalaria snails from the Colombian Amazon region and the Valles Interandinos.

\section{MATERIALS AND METHODS}

Snail populations - This study was carried out using snail populations from five localities in Colombia (Fig. 1), together with specimens identified as $B$. peregrina, $B$. straminea, B. intermedia, B. amazonica and B. kuhniana (Table) used for comparison. All the snails obtained from the field were examined for the presence of $S$. mansoni cercariae.

Morphological identification - Ten specimens of each population from Colombia were killed, their feet removed and conserved in ethanol. The remaining material was fixed and dissected for morphology of the shell and reproductive organs as described by Deslandes (1951) and Paraense $(1975,1976,1988)$.

DNA extraction - Total DNA was extracted from the feet of the snails by phenol-chloroform extraction and ethanol precipitation (Vidigal et al. 1994).

PCR-RFLP analysis - The entire ITS region (which includes the 5.8S rDNA gene together with the flanking ITS1 and ITS2 spacers) was amplified using the primers ETTS2 (5-TAACAAGGTTTCCGTAGGTGAA-3) and
ETTS1 (5-TGCTTAAGTTCAGCGGGT-3) (Kane \& Rollinson 1994). PCR amplification conditions were the same as used by Vidigal et al. (1998). Several enzymes employed in our previous studies with Biomphalaria snails (Vidigal et al. 1998, 2000a, Caldeira et al. 1998, 2000) were used here: DdeI, AluI, RsaI, MvaI and HaeIII. Digestion and RFLP analysis were performed as described by Vidigal et al. (1998).

\section{RESULTS}

Morphological identification - The snails were morphologically identified as $B$. amazonica (Fig. 2) and $B$. kuhniana (Figs 3-4). The vaginal corrugation, so characteristic of the $B$. straminea complex, show a difference among the B. kuhniana populations studied. Specifically, in the snails from Llanogrande (located at 2,100 m altitude), minimal swellings in the vaginal wall were found, in sharp contrast with the finding in snails from Acacias (530 $\mathrm{m}$ altitude).

All populations showed to be negative for S. mansoni cercariae. Some specimens of B. kuhniana from Acacias were infected with unidentified trematode cercariae.

Restriction profile analysis - DNA amplification with the ETTS1 and ETTS2 primers generated a fragment of approximately $1,300 \mathrm{bp}$ for all specimens. Fig. 5 shows the profiles obtained with the enzyme $D d e$ I for Brazilian populations of B. peregrina (lanes 1, 2), B. intermedia (lanes 3, 4), B. straminea (lanes 5, 6), B. kuhniana (lanes 7, 8), for B. kuhniana populations from Venezuela (lanes 9, 10) compared with populations from the Interandean Valleys (lanes 11 to 22). The four populations from the Interandean Valleys showed species-specific profiles for B. kuhniana. The enzymes AluI, RsaI, MvaI and HaeIII generated spe-
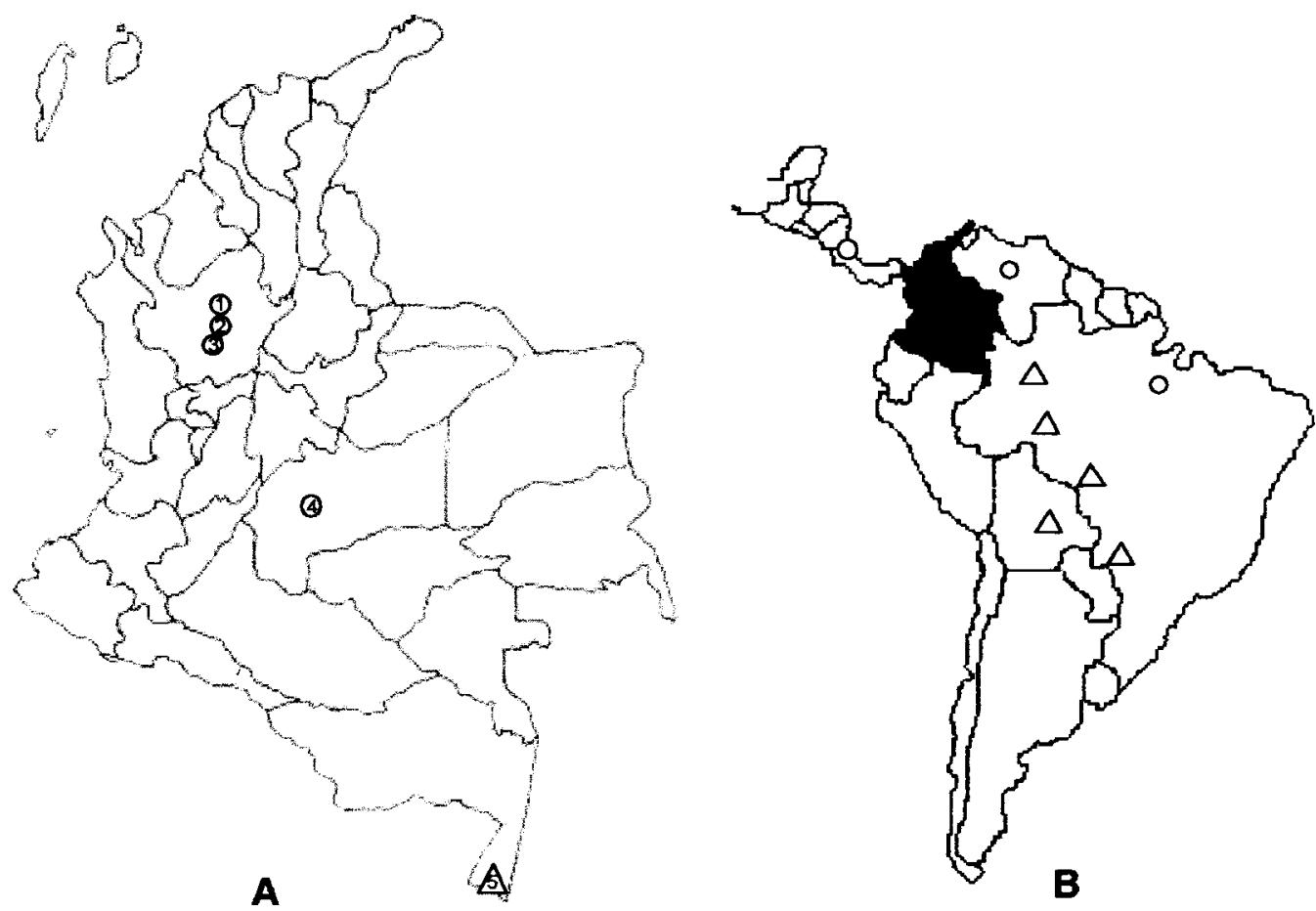

Fig. 1: geographic distribution of Biomphalaria kuhniana $(\bigcirc)$ and $B$. amazonica $(\triangle)$. A: in Colombia; municipality: 1 Segovia; 2 Porce; 3 Llanogrande; 4 Acacías; 5 Leticia; B: in Central and South America 
TABLE

Origin of the Biomphalaria species used in the study

\begin{tabular}{|c|c|c|c|c|}
\hline $\begin{array}{l}\text { Species of } \\
\text { Biomphalaria }\end{array}$ & Locality & State/Country & $\begin{array}{l}\text { Geographic } \\
\text { coordinates }\end{array}$ & Altitude \\
\hline \multirow[t]{6}{*}{ B. kuhniana } & Tucuruí & Pará/Brazil & 03S46/49W40 & 50 \\
\hline & Villa de Cura & Aragua/Venezuela & 10N01/67W29 & 550 \\
\hline & Segovia & Antioquia/Colombia $^{a}$ & 07N04/74W42 & 900 \\
\hline & Porce & Antioquia/Colombia & 06N91/75W13 & 950 \\
\hline & Acacías & Meta/Colombia & 04N35/71W48 & 523 \\
\hline & Llanogrande & Antioquia/Colombia & 06N06/75W27 & 2100 \\
\hline \multirow[t]{4}{*}{ B. amazonica } & Benjamin Constant & Amazonas/Brazil & 04S22/70W01 & 100 \\
\hline & Manaus & Amazonas/Brazil & 03S07/60W01 & 50 \\
\hline & Barão Melgaço & Mato Grosso/Brazil $^{a}$ & $16 \mathrm{~S} 11 / 55 \mathrm{~W} 41$ & 200 \\
\hline & Leticia & Amazonas/Colombia ${ }^{a}$ & 04S13/69W56 & 82 \\
\hline \multirow[t]{2}{*}{ B. straminea } & Picos & Piauí/Brazil $^{a}$ & 07S04/41W28 & 50 \\
\hline & Florianópolis & Santa Catarina/Brazil & 27S35/48W32 & 100 \\
\hline \multirow[t]{2}{*}{ B. intermedia } & Pindorama & São Paulo/Brazil & 21S11/48W54 & 150 \\
\hline & Itapagipe & Minas Gerais/Brazil & 19S54/49W22 & 400 \\
\hline \multirow[t]{2}{*}{ B. peregrina } & Alfenas & Minas Gerais/Brazil & 21S25/45W56 & 900 \\
\hline & Taim & Rio Grande do Sul/Brazil & $32 \mathrm{~S} 30 / 52 \mathrm{~W} 30$ & 50 \\
\hline
\end{tabular}

$a$ : laboratory populations

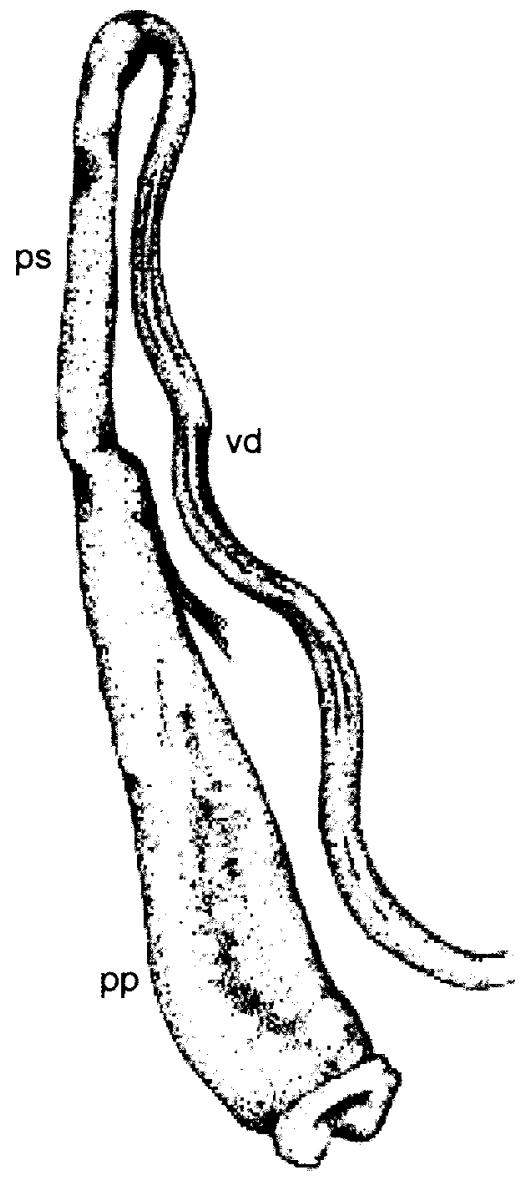

A

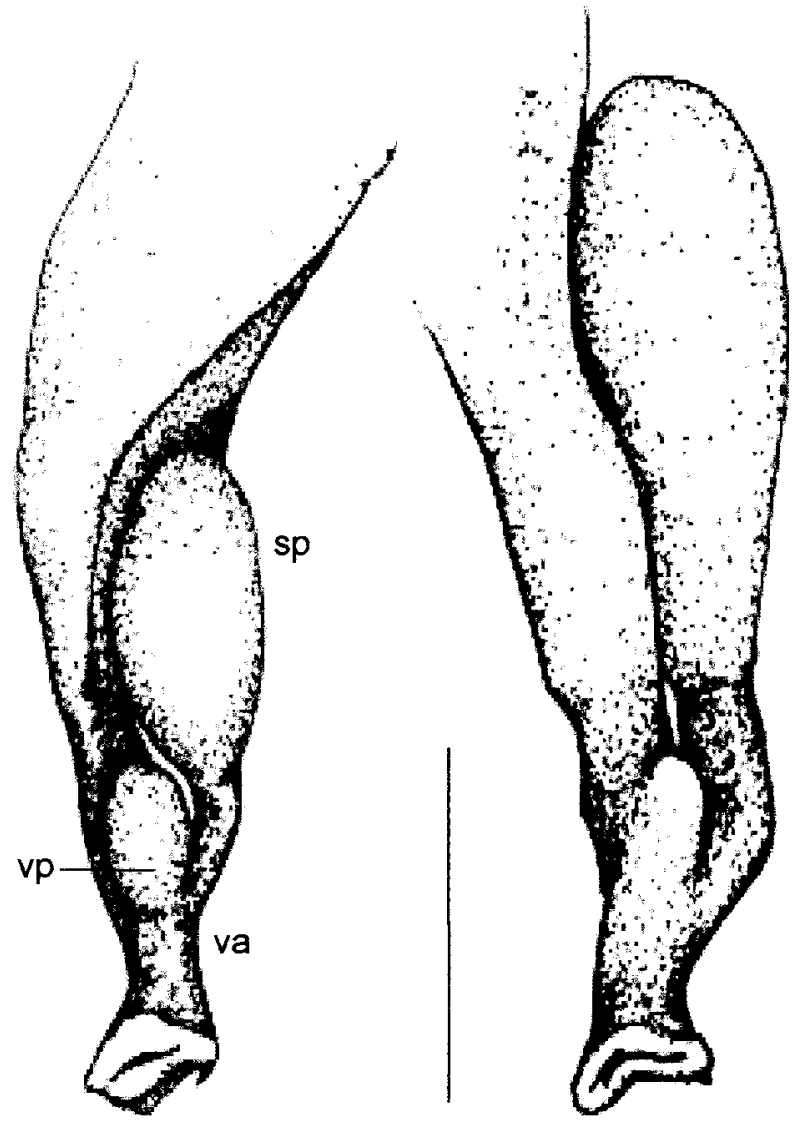

B

Fig. 2: Biomphalaria amazonica from Leticia, Colombia. A: penial complex, pp: prepuce, ps: penis sheath, vd: vas deferens; B: vaginal complex, sp: spermatheca, va: vagina, vp: vaginal pouch. $B a r=1 \mathrm{~mm}$ 
cies-specific profiles for the four B. kuhniana populations from the InterAndean Valleys (data not shown).

Fig. 6 shows the profiles obtained with the enzyme DdeI for Brazilian populations of B. amazonica (lanes 1 to 11 ; 16-17) compared with the samples from Colombian Amazonia (lanes 12 to 15). The profiles of the latter proved similar to each other and also to one of the three profiles of the Brazilian B. amazonica.

\section{DISCUSSION}

We report here for the first time the presence of $B$. amazonica in Colombia. The genitalia characters of this species correspond to those described by Paraense (1966). It does not present phenotypic plasticity but has welldefined morphological characters. On the other hand, the molecular profile of these snails sometimes shows three variants in the same locality (Vidigal et al. 2000a). Such intraspecific variation was further studied by Vidigal et al. (2000b), when the ITS2 region of Brazilian Biomphalaria snails was sequenced. Through PCR-RFLP analysis, using the same snail samples, these investigators could observe, in all trees, a polymorphism concerning the position of the three individuals (two from Amazonas and one from Mato Grosso, Brazil). Dejong et al. (2001) observed an intraspecific variation in two B. amazonica Brazilian snail populations (the same under study by Vidigal et al. 2000a, b) and in another from Bolivia, using combined data of the sequenced regions ITS1, ITS2 of rRNA gene and partial subunit 16S mitochondrial of rRNA gene of 23 Biomphalaria species (16 Neotropicals and 7 Africans). However, the Colombian specimens showed only one of the three profiles, reported by Vidigal (2000a), which mirrors less polymorphism when compared with Brazilian specimens. The phylogenetic relationship of $B$. amazonica, obtained through sequencing analyses by Vidigal et al. (2000b) and DeJong et al. (2001), with species of the same genus, from Neotropical and African regions, showed that $B$. amazonica possesses high affinity with the species of the complex $B$. straminea.

Among the populations of $B$. kuhniana under study presented variability of the vaginal corrugation, with more marked differences among the populations from Llanogrande, which showed very slight swellings, and from Acacias, which exhibited conspicuous corrugation. Interestingly, this kind of morphological variability was not detected at the intrapopulational level in contrast with the finding reported in B. kuhniana from Tucuruí, Brazil (Paraense 1988).

Owing to the morphological similarity and short genetic distance between $B$. straminea and $B$. kuhniana (Paraense 1988, Caldeira et al. 1998), these species are commonly confused by health technicians who are not specialized in Malacology. Indeed, snails from Venezuela identified as $B$. straminea were actually $B$. kuhniana (Caldeira et al. 2000). Such misclassification may also have occurred in Colombia since some populations of $B$.

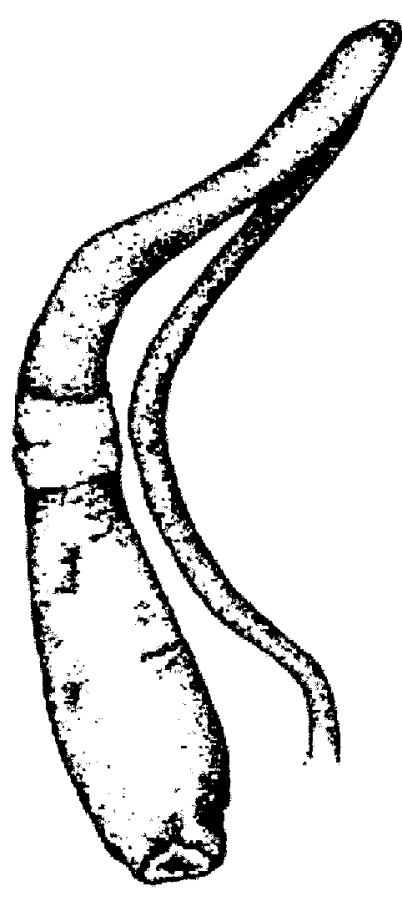

A
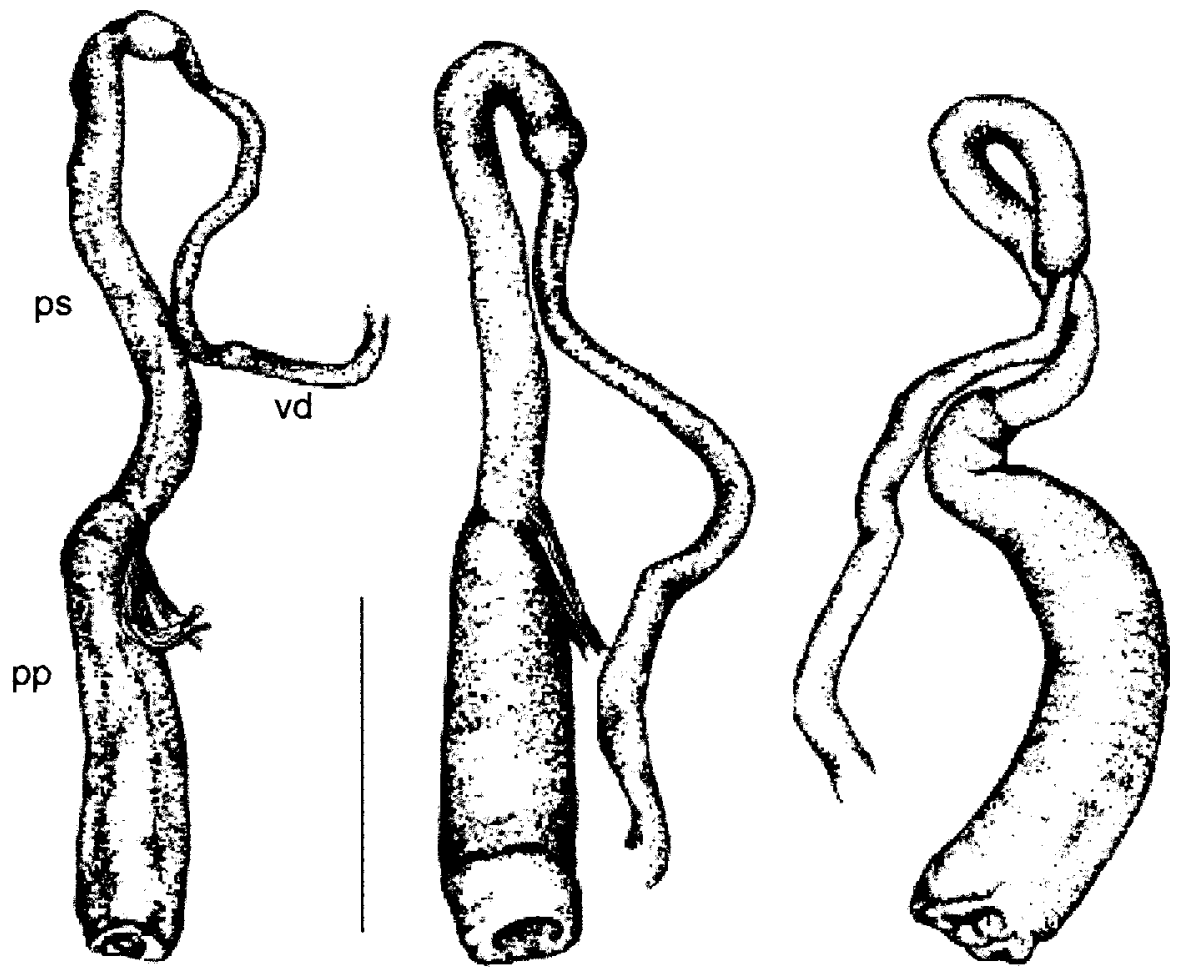

C

Fig. 3: penial complex of Biomphalaria kuhniana in different localities from Colombia: A: Llanogrande; B: Porce; C: Segovia; D: Acacías, pp: prepuce, ps: penis sheath, vd: vas deferens. Bar $=1 \mathrm{~mm}$ 
kuhniana, previously identified as $B$. straminea (Velásquez \& Vélez 1999), were molecularly characterized as $B$. kuhniana in the present study.

Caldeira et al. (1998), by using PCR-RFLP analysis of the ITS region of rRNA of $B$. straminea, $B$. intermedia, $B$. kuhniana and $B$. peregrina observed the cluster of three groups, which comprise: I) B. straminea and B. kuhniana; II) $B$. intermedia and III) B. peregrina. Groups I and II are more closely related while the third one showed to be a distant group. It was very clear the close relationship be- tween $B$. straminea and $B$. kuhniana, and despite the morphological similarity of $B$. straminea and $B$. intermedia with $B$. peregrina, it could not be included in the complex, which is supported by the morphological information reported by Paraense (1988). Following this, Vidigal et al. (2000b), through the sequencing of ITS2 of rRNA of the ten Brazilian Biomphalaria species, confirmed that $B$. kuhniana (from Venezuela and Brazil) is more closely related with $B$. straminea (from Brazil) than with $B$. intermedia (from Brazil). Afterwards, Dejong et al. (2001)
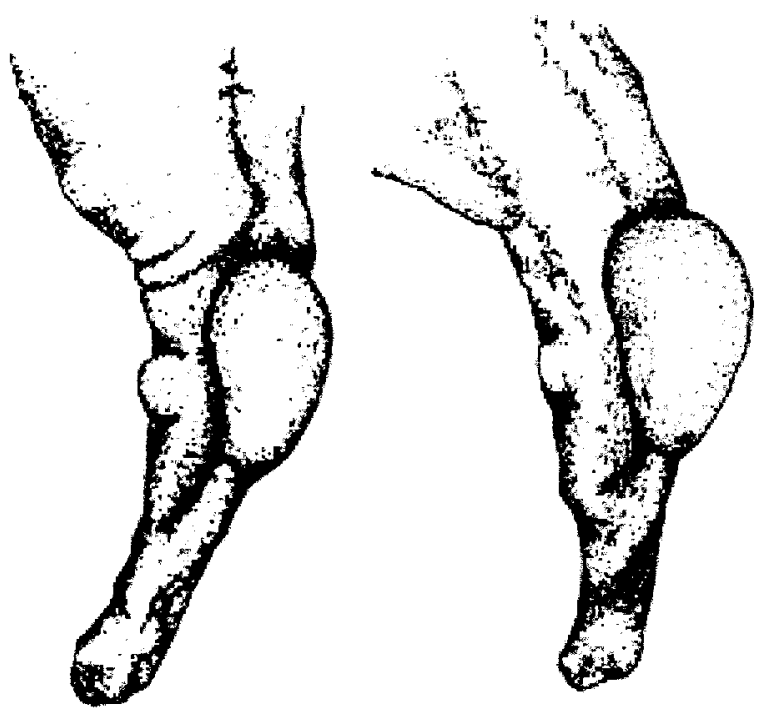

A
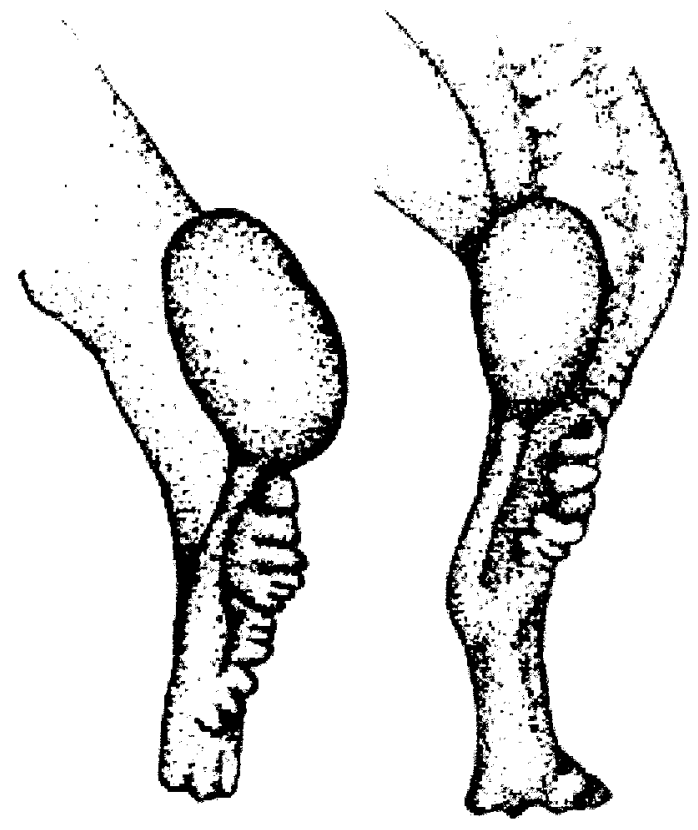

C

Fig. 4: diversity of vaginal corrugation in Biomphalaria kuhniana from Colombia: A: Llanogrande; B: Porce; C: Segovia; D: Acacías; sp: spermateca, va: vagina. $\mathrm{Bar}=1 \mathrm{~mm}$
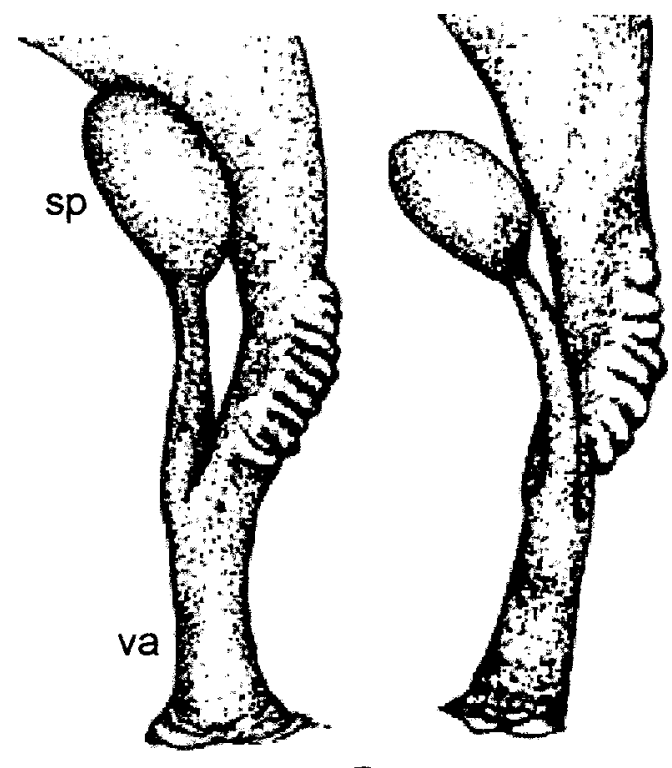

B
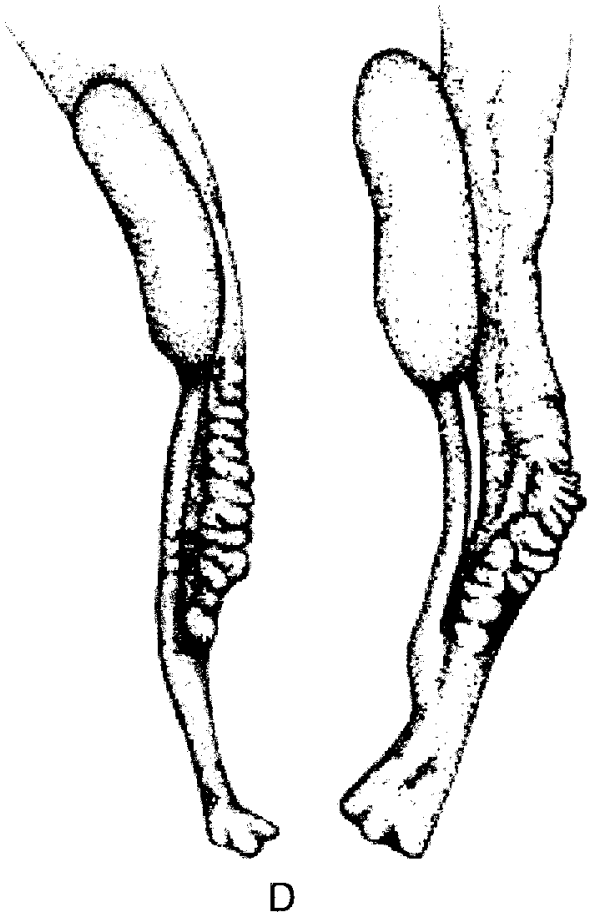
observed that, among the 23 Biomphalaria species studied, the most closely related group was that formed by $B$. straminea (Brazil), B. kuhniana (Dominica, Colombia and Venezuela) and $B$. intermedia (Paraguay). However, these authors remark that when the region $16 \mathrm{~S}$ was separately analyzed, two groups were then formed: (1) B. straminea
(Pará, Brazil) and B. kuhniana; (2) B. straminea (São Paulo, Brazil) and B. intermedia. Only after the analysis of the three DNA regions was it possible to observe the cluster of a single group. These authors speculate about a possible hybridization among these species, which could explain the close relationship among them. It is also impor-

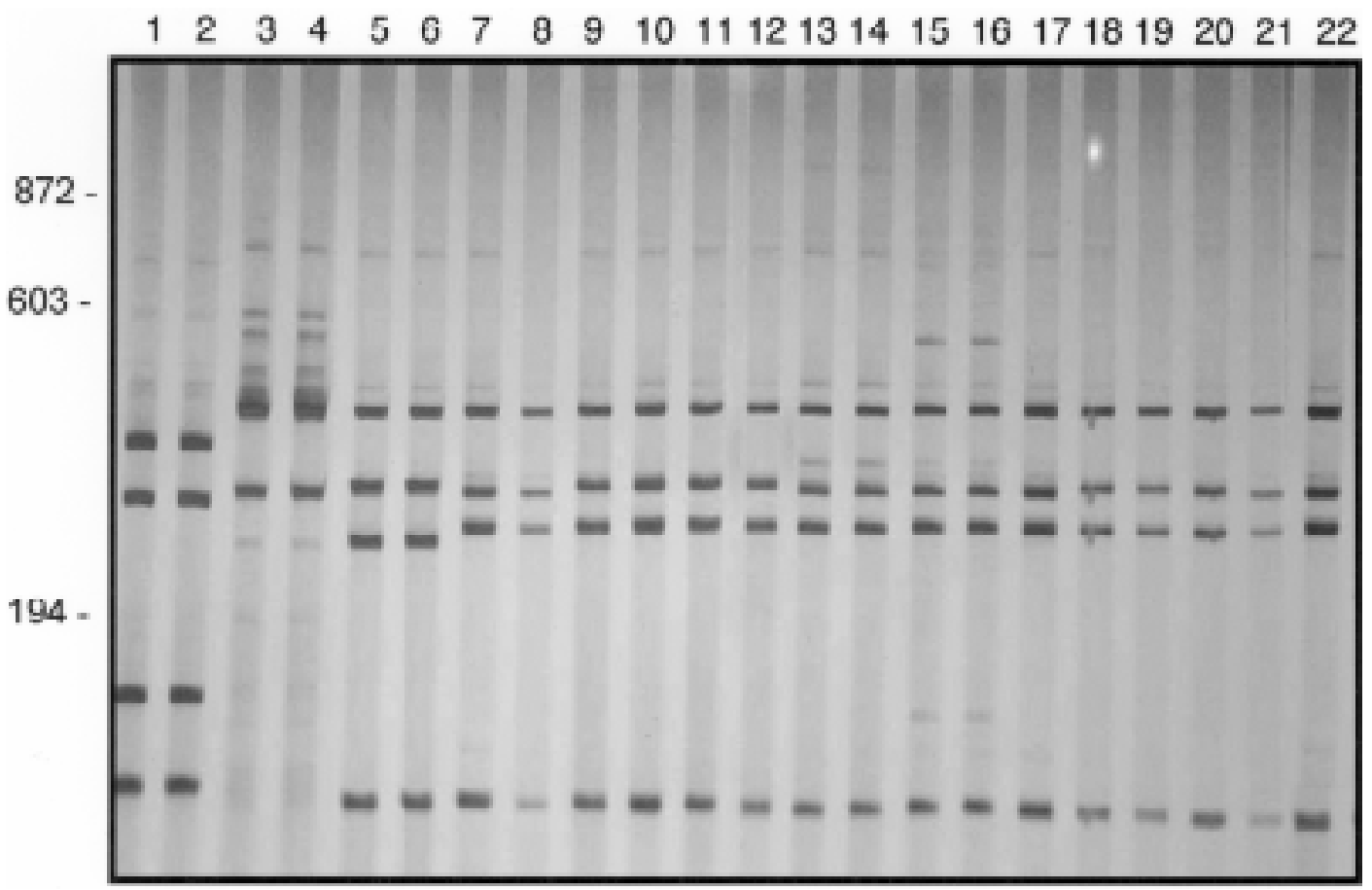

Fig. 5: silver-stained 6\% polyacrylamide gels showing restriction fragment length polymorphism profiles obtained after digestion of the rDNA internal transcribed spacer with DdeI enzyme. Biomphalaria peregrina - Lanes: 1 - Alfenas (Minas Gerais, Brazil); 2 - Taim (Rio Grande do Sul, Brazil); B. intermedia: 3 - Pindorama (São Paulo, Brazil); 4 - Itapagipe (Minas Gerais, Brazil); B. straminea: 5 - Picos (Piauí, Brazil); 6 - Florianópolis (Santa Catarina, Brazil); B. kuhniana: 7, 8 - Tucuruí (Pará, Brazil); 9, 10 - Villa de Cura (Aragua, Venezuela); 1113 - Segovia (Antioquia, Colombia); 14-16 - Porce (Antioquia, Colombia); 17-19 - Acacías (Meta, Colombia); 20-22 - Llanogrande (Antioquia, Colombia).

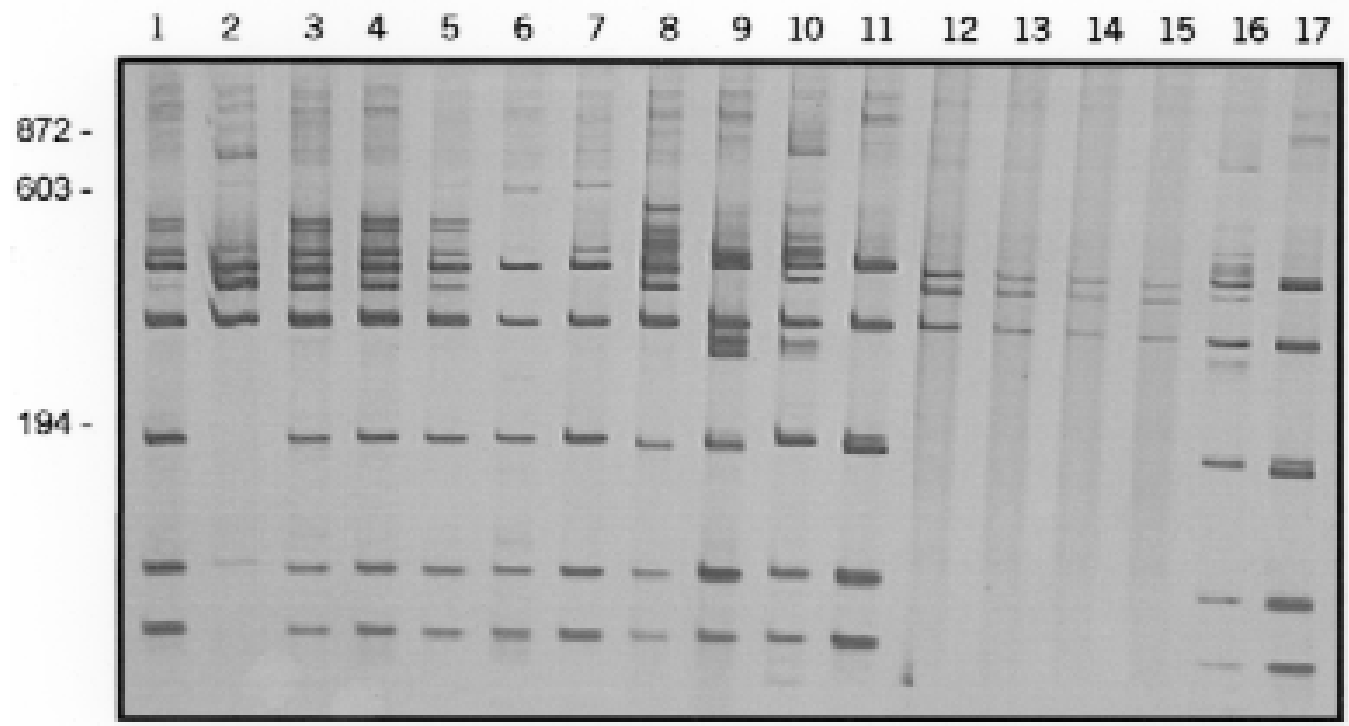

Fig. 6: silver-stained $6 \%$ polyacrylamide gels showing the restriction fragment length polymorphism profiles obtained by digesting the rDNA internal transcribed spacer with DdeI enzyme. Biomphalaria amazonica - Lanes: 1-5 - Benjamim Constant (Amazonas, Brazil); 68 - Barão de Melgaço (Mato Grosso, Brazil); 9-11 - Manaus (Amazonas, Brazil); 12-15 - Colombian Amazon (Amazonas, Colombia); 1617 - Manaus (Amazonas, Brazil). 
tant to remark that for Venezuela, country considered the type-locality of $B$. straminea, such species appear not to exist anymore, as recently reported by Caldeira et al. (2000), perhaps suggesting a misclassi-fication of the species, or, yet, a progressive substitution of $B$. straminea for $B$. kuhniana.

Therefore, the correct identification of these snails is of great importance since it allows the detection of species in areas of schistosomiasis transmission, as well as in areas free of the disease, which might become schistosomiasis foci, owing to the presence of natural or experimentally susceptible species. Thus, the methodology using PCR-RFLP proved to be effective for the characterization of Colombian Biomphalaria snails since it was able to confirm the classical morphologic identification.

\section{ACKNOWLEDGMENTS}

To Dr W Lobato Paraense, Department of Malacology, Instituto Oswaldo Cruz, Rio de Janeiro, for confirming the identification of Biomphalaria snails from Colombia; to Dr Sandra Uribe Soto, Universidad Nacional, Medellín for logistic support for the trip to Brazil; to Dr Piedad Vitoria Daza and Ariel Rodriguez for collecting specimens in Meta; to Mauricio Rodriguez for collecting and sending Colombian snail specimens and, finally, to the biologist María Carmenza Hincapie for the drawings.

\section{REFERENCES}

Agbo EC, Majiwa PAO, Claassen EJHM, Roos MH 2001. Measure of molecular diversity within the Trypanosoma bruce $i$ subspecies Trypanosoma brucei brucei and Trypanosoma brucei gambiense as revealed by genotypic characterization. Exp Parasitol 99: 123-131.

Baker HB 1930. The mollusca collected by the University of Michigan Williamson Expedition in Venezuela. Occ Pap Mus Zool Univ Mich 210: 1-95.

Barbosa FS 1968. Biomphalaria straminea (Dunker) en Colombia. Antioquia Med 16: 753-758.

Caldeira RL, Vidigal THDA, Matinella L, Simpson AJG, Carvalho OS 2000. Identification of planorbids from Venezuela by polymerase chain reaction amplification and restriction fragment length polymorphism of ITS of the RNA ribosomal gene. Mem Inst Oswaldo Cruz 95: 171-177.

Caldeira RL, Vidigal THDA, Paulinelli ST, Simpson AJG, Carvalho OS 1998. Molecular identification of similar species of the genus Biomphalaria (Mollusca: Planorbidae) determined by a PCR-RFLP. Mem Inst Oswaldo Cruz 93: 219-225.

Carvalho OS, Massara CL, Rocha RS, Katz N 1989 Esquistossomose mansoni no sudoeste do Estado de Minas Gerais (Brazil). Rev Saúde Publ São Paulo 23: 341-344.

Carvalho OS, Nunes IM, Caldeira RL 1998. First report of Biomphalaria glabrata in the State of Rio Grande do Sul, Brazil. Mem Inst Oswaldo Cruz 93: 39-40.

Carvalho OS, Rocha RS, Massara CL, Katz N 1988 Primeiros casos autóctones de esquistossomose mansoni em região do noroeste do Estado de Minas Gerais (Brazil). Rev Saúde Publ São Paulo 22: 237-239.

Clark TL, Meinke LJ, Foster JE 2001. PCR-RFLP of the mitochondrial cytochrome oxidase (subunit 1) gene provides diagnostic markers for selected Diabrotica species (Coleoptera : Chrysomelidae). Bull Entomol Res 91: 419-427.

Corrêa LR, Paraense WL 1971. Susceptibility of Biomphalaria amazonica to infection with two strains of Schistosoma mansoni. Rev Inst Med Trop São Paulo 13: 387-390.

DeJong RJ, Morgan JA, Paraense WL, Pointier JP, Amarista M, Ayeh-Kumi PF, Babiker A, Barbosa CS, Bremond P, Canese, AP, de Souza CP, Dominguez C, File S, Gutierrez A, Incani RN, Kawano T, Kazibwe F, Kpikpi J, Lwambo NJS, Mimpfoundi R, Njiokou F, Noel Poda J, Sene M, Velasquez LE, Yong M, Adema CM, Hofkin BV, Mkoji GM, Loker ES 2001. Evolutionary relationships and biogeography of Biomphalaria (Gastropoda: Planorbidae) with implications regarding its role as host of the human bloodfluke, Schistosoma mansoni. Mol Biol Evol 18: 22252239.

Deslandes N 1951. Técnica de dissecação e exame de planorbídeos. Rev Serv Esp Saúde Púb 4: 371-382.

Dorval MEC, Silva RP 1990. Biomphalaria amazonica Paraense, 1966 in the State of Mato Grosso do Sul, Brazil (Mollusca, Pulmonata, Planorbidae). Mem Inst Oswaldo Cruz 85: 117118.

Dunker W 1848. Diagnoses specierum novarum generis planorbis collectionis Cumingianae. Proc Zool Soc London: 40-43.

Dynes C, Fleming CC, Murchie AK 2001. Genetic variation in native and introduced populations of the 'New Zealand flatworm', Arthurdendyus triangulatus. Ann Appl Biol 139: 165-174.

Floch H, Fauran P 1954a. Essais infructueux d'infection expérimentale de Tropicorbis kuhnianus (Clessin) par Schistosoma mansoni. Bull Soc Pathol Exot 47: 452-459.

Floch H, Fauran P 1954b. Bilharziose intestinale et Tropicorbis kühnianus (Clessin) en Guyane Française. Arch Inst Pasteur Guyane Française 15: 1-7.

Floch H, Lajudie P 1945. Sur les bilharzioses en Guyane Française. Inst Pasteur Guyane Française et Inini 119: 1-5.

Hope M, McManus DP 1994. Genetic variations in geographically isolated populations and subspecies of Oncomelania hupensis determined by a PCR-based RFLP method. Acta Trop 57: 75-82.

Kane RA, Rollinson D 1994. Repetitive sequences in the ribosomal DNA internal transcribed spacer of Schistosoma haematobium, Schistosoma intercalatum and Schistosoma mattheii. Mol Biochem Parasit 63: 153-156.

Malek EA 1985. Snails Hosts of Schistosomiasis and Other Snail-transmitted Diseases in Tropical America: a Manual, Pan American Health Organization, Scientific Publication no. 478,325 pp.

Martens E 1873. Die Binnenmollusken Venezuela's. Festschrift zur Feier des hundertjährigen Bestehens der Gesellschaft Naturforschender Freunde zu Berlin, Ferd, Dümmlers Verlagsbuchhandlung, Harrwitz und Gossman, Berlin, p. 157-225.

Paraense WL 1963. The nomenclature of Brazilian planorbids. III. Australorbis stramineus (Dunker, 1948). Rev Bras Biol 23: 1-7.

Paraense WL 1966. Biomphalaria amazonica and B. cousini, two new species of Neotropical planorbid mollusks. Rev Brazil Biol 26: 115-126.

Paraense WL 1975. Estado atual da sistemática dos planorbídeos brazileiros. Arq Mus Nac 55: 105-128.

Paraense WL 1976. A natural population of Helisoma duryi in Brazil. Malacology 15: 360-376.

Paraense WL 1983. A survey of planorbid molluscs in the Amazonian region of Brazil. Mem Inst Oswaldo Cruz 78: 343-361.

Paraense WL 1988. Biomphalaria kuhniana (Clessin, 1883), planorbid mollusc from South America. Mem Inst Oswaldo Cruz 83: 1-12.

Paraense WL, Corrêa LR 1973. Susceptibility of Biomphalaria peregrina from Brazil and Ecuador to two strains of Schis- 
tosoma mansoni. Rev Inst Med Trop São Paulo 15: 127130.

Paraense WL, Corrêa LR 1985. Further experiments on susceptibility of Biomphalaria amazonica to Schistosoma mansoni. Mem Inst Oswaldo Cruz, 80: 259-262.

Pointier JP, Paraense WL, Dejong RJ, Loker ES, Barques MD, Mas-Coma S 2002. A potencial snail host of schistosomiasis in Bolivia: Biomphalaria amazonica Paraense, 1966. Mem Inst Oswaldo Cruz 97: 793-796.

Spatz L, Vidigal THDA, Caldeira RL, Dias Neto E, Cappa SMG, Carvalho OS 1999. Study of Biomphalaria tenagophila, B. t. guaibensis and B. occidentalis by polymerase chain reaction amplification and restriction enzyme digestion of the ribosomal RNA gene intergenic spacer. J Moll Stud 65: 143-149.

Stothard JR, Rollinson D 1997. Molecular characterization of Bulinus globosus and B. nasutus on Zanzibar, and an investigation of their roles in the epidemiology of Schistosoma haematobium. Trans R Soc Trop Med Hyg 91: 353-357.

Stothard JR, Hughes S, Rollinson D 1996. Variation within the internal transcribed spacer (ITS) of ribosomal DNA genes of intermediate snail hosts within the genus Bulinus (Gastropoda: Planorbidae). Acta Trop 61: 19-29.

Uribe C 1950. Contribución al estudio de algunos tremátodos larvarios de Colombia. Rev Acad Cienc Exact Fis Nat 4: 526.

Velásquez LE, Vélez ID 1999. Could Biomphalaria straminea associated with Piaractus brachypomus cultures constitute a potential epidemiological risk for Schistosoma mansoni in Colombia? Abstracts of the VII International Symposium on Schistosomiasis, Rio de Janeiro, p. 165.

Verkaar ELC, Nijman IJ, Boutaga K, Lenstra JA 2002. Differentiation of cattle species in beef by PCR-RFLP of mitochondrial and satellite DNA. Meat Science 60: 365-369.

Vidigal THDA, Caldeira RL, Simpson AJG, Carvalho OS 2000a. Further studies on the molecular systematics of Biomphalaria snails from Brazil. Mem Inst Oswaldo Cruz. 95: 57-66.

Vidigal THDA, Dias Neto E, Carvalho OS, Simpson AJG 1994. Biomphalaria glabrata: extensive genetic variation in Brazilian isolates by random amplified polymorphic DNA analysis. Exp Parasitol 79: 187-194.

Vidigal THDA, Kissinger JC, Caldeira RL, Pires ECR, Monteiro E, Simpson AJG, Carvalho OS 2000b. Phylogenetic relationships among Brazilian Biomphalaria species (Mollusca: Planorbidae) based upon analysis of ribosomal ITS 2 sequences. Parasitology 121: 611-620.

Vidigal THDA, Spatz L, Nunes DN, Simpson AJG, Carvalho OS, Dias Neto E 1998. Biomphalaria spp: identification of the intermediate snail hosts of Schistosoma mansoni by polymerase chain reaction simplification and restriction enzyme digestion of the ribosomal RNA gene intergenic spacer. Exp Parasitol 89: 180-187. 